\title{
Primary central nervous system lymphomas in immunocompetent patients
}

\author{
T. Alécio-Mattei; J. Alécio-Mattei; P.H. Aguiar and *R. Ramina
}

Pinheiros Neurosurgery Clinic. São Paulo. Brazil. *Institute of Neurology Curitiba. Brazil

\begin{abstract}
Objetctives. Primary central nervous system lymphoma (PCNSL) is a rare patology and is most often seen in immunodeficient patients. This article presents our casuistic of PCNSL in immunocompetent patients and make a literature review on this issue with focus on recent advances, investigations, and controversies in diagnosis and management of this patology.

Matherial and methods. Nine patients operated in the last years in our clinics are analysed in relation to sex, age, time of symptoms, procedures and adjuvant treatment. Posteriorly the results are compared with those in the preview literature.

Results. The age ranged from 44-68 years (middle of 66 years); $62,5 \%$ of the patients were female. The mean time of symptoms, when the diagnostic was made, was 3.2 months (range 1-6 months). The most common symptoms were hemiparesis (present in $\mathbf{7 5 \%}$ of the patients) headache $(37.5 \%)$ seizures $(25 \%)$ and ataxia $(25 \%)$. The most common localization was the parietal, frontal and temporal lobe surface with $25 \%$ of the patients for each localization. Five patients $(50 \%)$ were treated with stereotactic biopsy, three with surgery $(37.5 \%)$ and one $(12.5 \%)$ with both of them. Five patients $(62,5 \%)$ were submitted to pos-operative radiotherapy as adjuvant treatment. In relation to the hystology, the most common cell type was Difuse B Cells.

Conclusions. This study demonstrated that complete surgical ressection followed by radiotherapy have shown good results. In opposition to the literature, the authors regards chemotherapy as a secondary line treatment and recommends its use only in some selected cases.
\end{abstract}

KEY WORDS: Brain lymphoma. Immunocompetent. Malignant lymphoma. PCNLS

Recibido: 18-08-04. Aceptado: 19-05-05
Linfomas primarios del sistema nervioso central en pacientes immunocompetentes

Resumen

Objetivos. En este trabajo presentamos nuestra casuística de linfomas cerebrales primarios en pacientes immunocompetentes comparandolo con los datos previos de la literatura, con especial enfoque en los recientes avaces, investigaciones, $y$ controversias acerca del diagnóstico y manejo terapéutico de estas patologías.

Material y método. Nueve pacientes operados el año pasado en nuestra clínica con diagnóstico de PCNLS son analizados en relación al sexo, edad, tiempo de sintomatología, procedimientos y tratamiento. Posteriormente, los resultados son comparados con los de la literatura.

Resultados. La edad varió entre 44-68 años (media de 60,6 años); 62,5\% de los pacientes fueron del sexo femenino; el tiempo medio de duración de los síntomas antes del diagnóstico de la enfermedad varió de 1-6 meses, con un rango medio de 3,2 meses. Los síntomas clínicos más frecuentes fueron : hemiparesia $(\mathbf{7 5 \%})$, cefalea $(37,5)$, crisis convulsivas $(25 \%)$ y ataxia $(25 \%)$. Las localizaciones predominaron en las superficies de los lóbulos parietal, temporal y frontal con un $25 \%$ para cada una de las localizaciones citadas. Cinco pacientes $\mathbf{( 5 0 \% )}$ fueron tratados con biopsia estereotáxica, tres con cirugía $(37.5 \%)$ y uno $(12.5 \%)$ con ambas. Cinco pacientes $(62,5 \%)$ fueron sometidos a radioterapia postoperatoria como tratamiento adyuvante. En relación con el tipo histológico predominó el linfoma de células difusas tipo $B$.

Conclusiones. Este estudio demostró que la resección quirúrgica, combinada con biopsia por esterotaxia y la radioterapia dan buenos resultados. Los

Abbreviations. IICP: increased intracranial pressure. NHL: non Hodgkin's lymphomas. PCNSL: primary central nervous system lymphomas 
autores recomiendan la quimioterapia solamente como segunda línea de tratamiento, en pacientes seleccionados.

PALABRAS CLAVE: Immunocompetente. Linfomas cerebrales. Linfomas malignos. PCNLS.

\section{Introduction}

Primary central nervous system lymphoma (PCNSL) is rare and is most oftn seen in inmunodeficient patients. These tumors constitute $0.3-1.5 \%$ of all intracranial neoplasms in patients without IIDS $^{26}$.

The majority are the Non-Hodgkin type and are high grade $^{19}$. They are mainly B-cell lymphomas $(96.4 \%)$ were T-cell type tumors ${ }^{3,21}$. Nevertheless, clinical manifestations, management, and outcome of T-cell lymphoma (3.6\% of all PCNSL) are very similar to those of B-cell lymphoma ${ }^{28}$. Primary Burkitt lymphoma of the CNS in inmunocompetent individuals has rarely been reported ${ }^{19}$. The CNS lymphomas are associated with other CNS tumours as pontocerebellar angle schwannoma ${ }^{17}$, anaplastic oligodendrogliomas ${ }^{13}$.

\section{Matherial and methods}

Nine patients operated in the last years in our clinics are analysed in relation to sex, age, time of symptoms, procedures and adjuvant treatment. The neuroradiological exams, history of the disease, prescriptions, evolution, surgery report and anatomo-pathological exams are reviewed and analysed. Posteriorly the results are compared with those in the preview literature.

\section{Results}

The middle age of our series varied from 44-68 years, with a mean age of 60,6 years. The female sex was predominant with $62,5 \%$ of our patients. The time of symptoms at presentation ranged from 1-6 months with a mean of 3,2 months. The most common symptoms found at presentation were hemiparesis $(75 \%)$, headache $(37,5 \%)$, seizures $(25 \%)$ and ataxia (25\%). Other clinical finds were afasia, Parinaud syndrome, nistagmus, dismetry and intracranial hypertension. Histollogically there were predominance of Difuse B Type, followed by Big B Cells Type. In relation to anatomy, the tumors affected indistinctly the parietal, frontal and temporal lobe with the same frequency $(25 \%)$. Other affected localizations were Sylvian fissure, paraventricular and posterior thalamic region.

Five patients were diagnosed with stereotaxic biopsy $(56 \%)$, three patients were directly operated $(37,5 \%)$ and one patient was treated with both procedures $(12,5 \%)$. Five patients were submited to radiotherapy in the postoperatory (56\%) and, one of these received also chemotherapy with $\mathrm{BCNU}+$ Procarbazina + Vincristina. We had a patient that did not accepted surgery or radiotherapy and was treated with pulsotherapy with solumedrol.

In table 1 we present the resume of data of our patients:

\section{Discussion}

\section{Epidemiology}

Although primary central nervous system lymphomas (PCNSL) represent only $1 \%$ of all non-Hodgkin's lymphomas (NHLs) ${ }^{1}$ in recent years there has been a dramatic increase in the frequency of PCNSL in the immunocompromised and immunocompetent patient ${ }^{21}$. In the past 10 years the incidence has tripled in patients without AIDS $^{26}$.

Most patients presenting PCNSL are in the end of the fifth decade and the begining of the $\operatorname{sixth}^{3,5,18,23}$. Our results were similiar, with mean age of 60,6 years. In our series $67,5 \%$ of the patients with PCNSL were female, concording with the previous literature ${ }^{18}$. Literature relates that about $75 \%$ of PCNSL patients have unifocal disease with a supratentorial location in $87 \%^{3}$. In our series all the patients had focal disease and all the tumors were supratentorial.

\section{Signs and symptoms}

The time from first symptoms to the diagnosis ranged from a few days to 5 months. In our series, most of the patients had between 1 and 2 months of symptoms at the time of diagnosis. This is important because the good results with combined surgery and radiotherapy treatment demand early stage of the disease.

Headache and vomiting due to IICP (increased intracranial pressure) and corresponding neurofunctional disorders due to various location of the tumors are the main clinical manifestation. In the majority of patients, the leading symptoms are: headaches, motor weakness, aphasia and memory disturbance ${ }^{31}$.

In our study, we saw that tumours in parietal region usually affect the motor pathways leading to contralateral motor deficits in most of the patients. Seizures were also a frequent symptom in our series, although not related in previous reports.

Altough literature reports the frontal lobe as the most common site of involvement ${ }^{5}$, we also saw a high prevalence of tumours in temporal and parietal lobe. Tumor location in basal ganglia, corpus callosum, or fornix, infiltration of periventricular ependyma or a mirror pattern are strongly suggestive of a lesion of lymphomatous origin ${ }^{3}$. 


\begin{tabular}{|c|c|c|c|c|c|c|c|}
\hline \multicolumn{8}{|c|}{$\begin{array}{c}\text { Table } 1 \\
\text { Summary of clinical data }\end{array}$} \\
\hline Name/Sex & Localization & $\begin{array}{l}\text { Age } \\
\text { (years) }\end{array}$ & $\begin{array}{l}\text { Tm } \\
(\mathrm{mes})\end{array}$ & Histology & Symptoms & Procedure & Treatment \\
\hline $\begin{array}{l}\text { 1) VSF/ } \\
\text { male }\end{array}$ & Parietal lobe & 62 & 1 & $\begin{array}{l}\text { Difuse, B } \\
\text { cells }\end{array}$ & $\begin{array}{l}\text { Left hemiparesy } \\
\text { hemihypoestesy }\end{array}$ & $\begin{array}{l}\text { Stereotacti } \\
\text { c biopsy }\end{array}$ & Radiotherapy \\
\hline $\begin{array}{l}\text { 2) } \mathrm{AR} / \\
\text { male }\end{array}$ & Temporal lobe & 66 & 2 & $\begin{array}{l}\text { Great B } \\
\text { cells }\end{array}$ & $\begin{array}{l}\text { Aphasia, right } \\
\text { hemiparesy }\end{array}$ & $\begin{array}{l}\text { Stereotacti } \\
\text { c biopsy/ } \\
\text { surgery }\end{array}$ & Radiotherapy \\
\hline $\begin{array}{l}\text { 3) JA/ } \\
\text { male }\end{array}$ & Temporal lobe & 64 & 1 & $\begin{array}{l}\text { Difuse, B } \\
\text { cells }\end{array}$ & $\begin{array}{l}\text { Epileptic crisis, } \\
\text { left hemiparesis }\end{array}$ & Surgery & Radiotherapy \\
\hline $\begin{array}{l}\text { 4) } \mathrm{JF} / \\
\text { female }\end{array}$ & Frontal & 58 & 3,5 & B cells & $\begin{array}{l}\text { Headache, right } \\
\text { hemiparesis, }\end{array}$ & Surgery & Radiotherapy \\
\hline $\begin{array}{l}\text { 5) MA/ } \\
\text { female }\end{array}$ & Frontal & 55 & 6 & B cells & $\begin{array}{l}\text { Headache, } \\
\text { epileptic crises }\end{array}$ & Surgery & None \\
\hline $\begin{array}{l}\text { 6) } \mathrm{MG} / \\
\text { female }\end{array}$ & $\begin{array}{l}\text { Parieto- } \\
\text { occipiatl }\end{array}$ & 44 & 1 & $\mathrm{~B}$ cells & $\begin{array}{l}\text { Headache and } \\
\text { Parinaud } \\
\text { syndrome }\end{array}$ & $\begin{array}{l}\text { Surgery } \\
\text { and } \\
\text { radiotherap } \\
\text { y refused } \\
\text { by the } \\
\text { family }\end{array}$ & $\begin{array}{l}\text { Pulsotherapy } \\
\text { with } \\
\text { solumedrol }\end{array}$ \\
\hline $\begin{array}{l}\text { 7) } \mathrm{AG} / \\
\text { female }\end{array}$ & $\begin{array}{l}\text { Posterior } \\
\text { callosum area }\end{array}$ & 68 & 2 & B cells & $\begin{array}{l}\text { Severe } \\
\text { intracranial } \\
\text { hypertension and } \\
\text { left hemiparesis }\end{array}$ & $\begin{array}{l}\text { Stereotacti } \\
\text { c biopsy }\end{array}$ & Radiotherapy \\
\hline $\begin{array}{l}\text { 8) } \mathrm{HW} / \\
\text { female }\end{array}$ & $\begin{array}{l}\text { Posterior } \\
\text { thalamus }\end{array}$ & 68 & 1 & $\begin{array}{l}\text { Great B } \\
\text { cells }\end{array}$ & $\begin{array}{l}\text { Ataxy, } \\
\text { hypoesthesy and } \\
\text { central facial } \\
\text { palsy }\end{array}$ & $\begin{array}{l}\text { Stereotacti } \\
\text { c biopsy }\end{array}$ & $\begin{array}{l}\text { Chemotherap } \\
\text { y (CCNU + } \\
\text { procarbazina } \\
\text { + vincristina) } \\
\text { radiotherapy } \\
\text { and } \\
\text { pulsotherapy } \\
\text { with } \\
\text { solumedrol }\end{array}$ \\
\hline
\end{tabular}

Some studies indicate that nodular intracerebral lesions can reveal asymptomatic systemic lymphoma. When brain lymphoma is suspected or diagnosed, systemic workup including clinical, biological and radiological examinations is mandatory before assessing the primary or secondary nature of the disease. Node areas, skin, testis, Waldeyer's ring and adjacent structures are of special interest and should be carefully explored ${ }^{10}$.
Although metastasis of PCNSL are not reported in the previous literature, in our series $25 \%$ of patients with primary brain linfomas showed dissemination to lungs, showing that these lesions are not only locally agressive but can also show distant malignancy. In our opinion, all patients diagnosticated with PCNSL must be submitted to complete clinical and imagenological investigation, in order to discard the possibility of further lesions. 


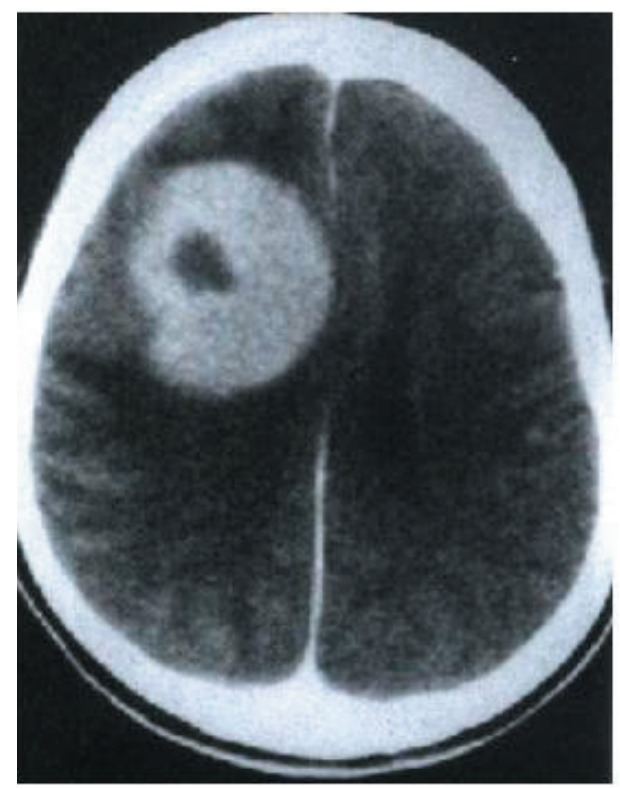

Figure 1. Unenhanced axial CT demonstrating a frontal hyperdense lesion with an irregular central hypodensisty. The histopathological diagnosis was primary CNS B cell agressive lymphoma (case 4).

\section{Diagnosis}

\section{Image Diagnostic}

Typical neuroradiological patterns of PCNSL are ${ }^{15}$ : -iso- or hyper-density $(85,5 \%)$ on unenhanced CT scan (Figure 1) with marked contrast enhancement $(87,7 \%)$. -infiltration/contact of leptomeningeal and/or ependymal spaces $(97,3 \%)$

-hyperintensity on T2 with moderate oedema $(80,3 \%)$ Peripheral edema may be seen in MRI (Figure 2). Images shows low-real signals in $\mathrm{T} 1$ phase, but enhanced signals in T2 phase (Figure 3$)^{31}$.

\section{Scintigraphy}

The differential diagnosis of PCNSL must be made with an abscess because computed tomography (CT) and magnetic resonance imaging (MRI) exams of both entilies can have the same ring-like contrast enhancement.

In this purpose, leucocyte scintigraphy is a valuable aid allowing the differentiation between an abscess and a neoplasic lesion. The 99mTc-HMPAO leucocyte scintigraphy is positive in all abscess cases ${ }^{27}$.

\section{SPECT}

Some authors suggest that 123I-IMP SPECT can help to differentiate malignant lymphoma from benign lesions and

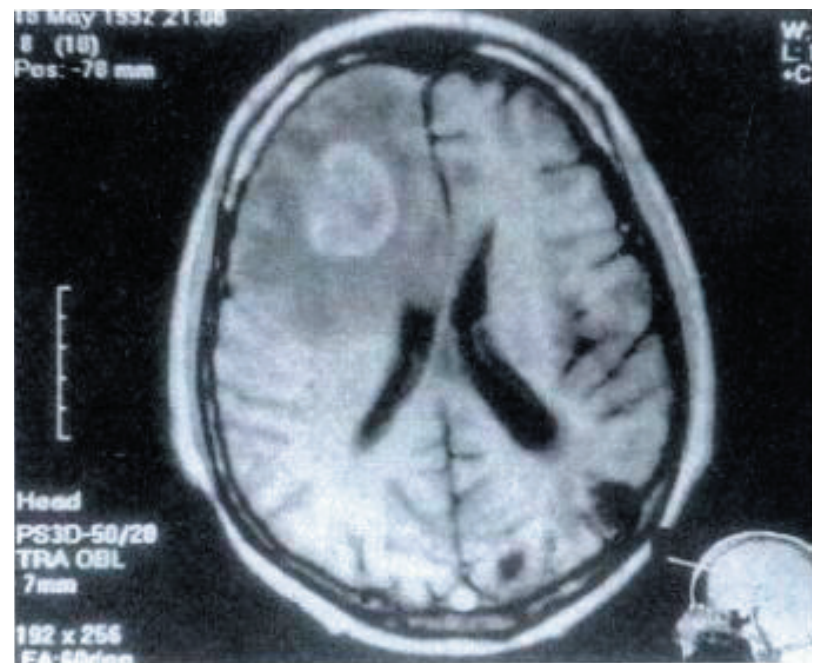

Figure 2. MRI T1 -weighted axial slice of a right frontal hypesignal linfoma presenting with important perilesional edema (case 5).
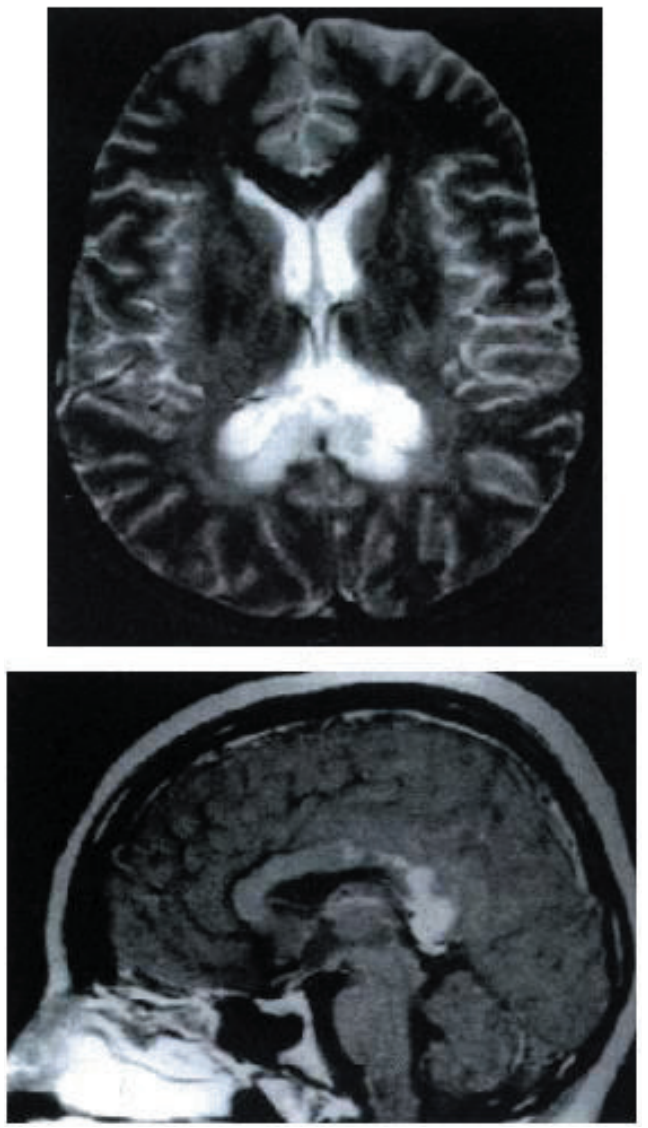

Figure 3. Up: Axial T2-MRI showing homogeneous hyperintense lesion within the splenium of the corpus callosum (Case 7)

Down: Enahnced sagittal T1 slice showing the posterior localization of the lesion.

The stereotactic biopsy showed a Primary CNS B cell linfoma. 
other malignant brain tumors. In the case of B-cell malignant lymphoma the 123I-IMP SPECT shows increased uptake on both early and delayed images diffuse large ${ }^{30}$.

\section{Stereotactic biopsy}

Stereotactic brain biopsy was used to establish diagnoses of conditions in patients with brain tumors. In a series of 273 computer-assisted stereotactic brain biopsy procedures $^{22}$, glial tumors accounted for the majority (44.4\%) of biopsied lesions; metastases (12.9\%) and lymphoma $(11.6 \%)$ were also relatively common

Due to the high probability of develop intracranial bleeding after this procedure, all patients must be treated with a coagulopathy protocol that included preoperative and postoperative administration of coagulation factors ${ }^{14}$. The stereotactic biopsy was used by us to confirm the diagnosis in those patients who were not in conditions to be submited to surgery. All these patients, after confirmed the suspect of PCNSL were sent to radiotherapy.

In only one patient stereotactic biopsy was followed by surgery and posterior radiotherapy. In this patient the diagnosis suspect was other and, when the histopathological exam showed a PCNSL, it was decided that the patient would be submited to complete resection followed by radiotherapy.

\section{Histopathology}

Histopathological work-up includes conventional and immunohistochemical stains perfomed on formalin fixed and paraffin embedded bioptical specimen ${ }^{15}$.The high percentage of accurate histopathological diagnosis in our study was based on:

-great mean sample volume per biopsy site

-great number of biopsies in patients suspected to have cerebral lymphomas

-MR-guided stereotactic procedures if the lesion was not clearly identifiable on CT scan.

Histologically the tumor mass is grayish in color often with a blussed borders (those located in brain surface often have rough borders) to the naked eye. Under microscope tumor cell may be seen around blood vessels with decreased cytosol (figure 4), pathologic rayokinesis and sometimes focal hemorrhage necrosis ${ }^{31}$ The predominant histologic types of primary intracranial non-Hodgkin's lymphoma are diffuse large cell type (38\%), large cell immunoblastic type $(21 \%)$, and diffuse mixed small and large cell type $(21 \%)^{24}$.

The histiocitic type of lymphoma is very rare. Nevertheless it can be easily due to its characteristic immunophenotype featuree: positive for CD68 and lysozyme; focally positive for $\mathrm{S}-100$ protein, CD45RB, and

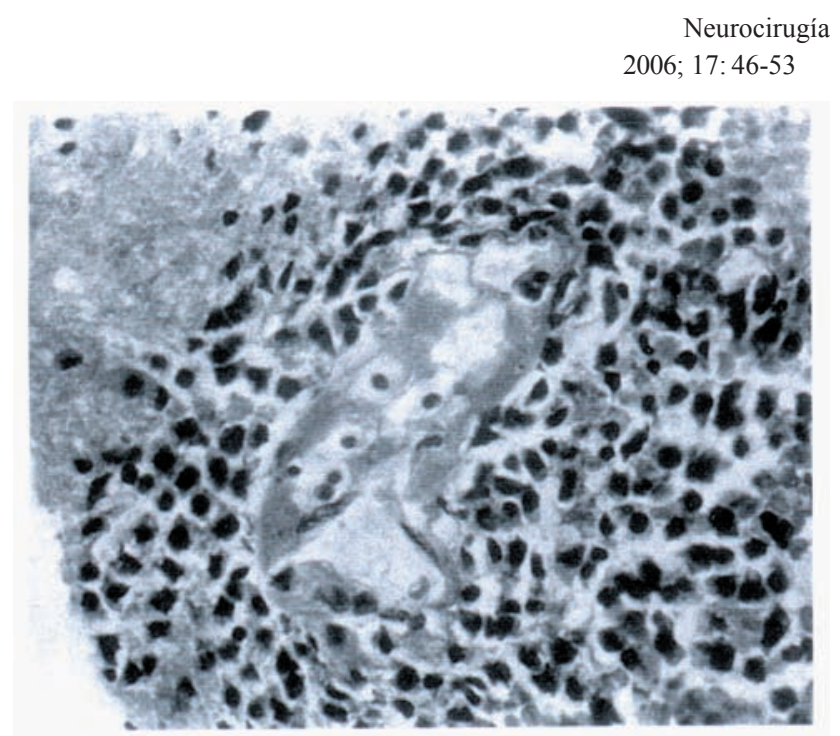

Figure 4. Histopathology of stereotactic biopsy showing small non-clived primary CNS lymphoma. Note the perivascular localization of linfocitic cells.

CD4; and negative for CD3, CD20, CD21/CD35, CD1a, CD30, ALK1, myeloperoxidase, glial fibrillary acidic protein, and cytokeratin ${ }^{11}$.

\section{Treatment}

\section{Surgery}

The majority of articles in current literature regards surgery as having little role (if any) in the treatment of PCNSL and that its utility is limited to obtaining adequate tissue for diagnosis. Nevertheless, there are some case reports of five years disease free after total surgical resection of PCNLS ${ }^{26,31}$.

We recommend surgery as gold standart therapy for the early excision combined with postoperatory irradiation, once it's curative if the diagnosis is precoce and it's more tolerable than chemotherapy.

\section{Radiotherapy}

Historically, radiotherapy has been the standard treatment modality for this disease and median survival was in the 15 -month range ${ }^{25}$. The radiation therapy has been proven to prolong survival but, its use is complicated by delayed neurological toxicity, particularly among the elderly ${ }^{20}$.

Although a high radiation dose was not associated with better prognosis ${ }^{16}$, better rates of complete radiographic response is observed following moderate doses of cranial irradiation (about 40 Gy followed by a 20 Gy boost to the tumor plus 2-cm margin). Although complete responders have a statistically significant survival advantage at 4 years, when compared with partial responders and nonresponders, 
the majority of patients who achieved complete response were dead of disease by 4 years following treatment. Based on this analysis there is no rationale for radiation dose escalation as a therapeutic strategy to combat PCNSL $^{9}$.

In addition, stereotactic radiosurgey with conventional radiotherapy may be an effective therapeutic strategy to control malignant lymphoma ${ }^{30}$. In our series patients submitted to stereotactic biopsy followed by radiotherapy had poorer results than those submitted to surgical resection plus radiotherapy.

\section{Chemotherapy}

Primary CNS lymphoma (PCNSL) is distinguished from other brain tumours by its striking response to chemotherapy. Nevertheless, chemotherapy is poorly tolerated and largely palliative in old patients. It must be remembered that the majority of PCNSL patients are older than 60 years, and therefore, will certainly find some kind of collateral effect of chemotherapy ${ }^{18}$.

Progress in understanding the physiology of the bloodbrain barrier (BBB) and the pharmacology of chemotherapeutic agents has substantially improved the treatment and prognosis of this disease ${ }^{20}$. Administration of high dose of methotrexate and/or cytosine arabinoside may improve survival ${ }^{12}$. Some authors recommend a therapeutic regime including surgery, intrathecal injection and chemotherapy, especially those drugs capable of going through the bloodbrain barrier, for example high dose methotrexate $\mathrm{MTX}^{32}$. MTX is the single most effective agent.

The goal of delivering an adequate dose of MTX to the brain and cerebrospinal fluid (CSF) has been achieved by a variety of strategies, including systemic high dose, intraarterial injection following pharmacological disruption of the blood-brain barrier (BBB) and intrathecal administration. Some authors showed that survival was not longer in patients receiving intrathecal chemotherapy ${ }^{6,12}$. A possible complication of the systemic chemotherapy is myelosuppression, and aseptic meningitis is related as result of intraventricular chemotherapy ${ }^{6}$. Treatment-related toxicity was manageable, however delayed neurotoxicity is seen in disease-free survivors.

MTX-based combination chemotherapy has yielded the best results but the prognosis of patients with CNS lymphomas remains significantly worse than comparable patients with systemic non-Hodgkin's lymphoma ${ }^{20}$.

\section{Multi-modality therapy}

The role of multi-modality therapy combining radiation therapy with chemotherapy (systemic, intrathecal, and/or intra-arterial) in PCNSL is controversial. Some authors relate that multi-modality therapy (chemotherapy plus radiotherapy) significantly enhances survival over patients treated with single modality therapy alone $e^{2,12,23-25}$. The hypothesis is that chemotherapy may enhance the radiation effect on normal brain tissue as well as in the tumor ${ }^{24}$.

Nevertheless some authors showed, in a randomized trial, that there is no evidence of a benefit from postradiotherapy chemotherapy with cyclophosphamide, doxorubicin, vincristine, and prednisone (CHOP) in immunocompetent adult patients with PCNSL18. An European survey recommends the treatment of primary intracerebral lymphoma with the following sequence: stereotactic biopsy sampling, chemotherapy with a methotrexate and anthracycline-based regimen, followed by cranial irradiation ${ }^{3}$.

\section{Corticosteroids}

Non-AIDS primary central nervous system lymphomas may respond totally or partially to corticosteroids. These corticoid-induced remissions seems to be very specific for this disease. They have been proposed as diagnostic test. The effect of these remissions on prognosis remains unknown.

Age was the only significant factor predicting remission. Duration of the first remission is of paramount importance on survival as well as the quality of first line therapy. In these conditions the absence of precise diagnosis due to corticoid-induced remissions could be dramatically deleterious ${ }^{11}$.

We used pulsotherapy with solumedrol in 2 patients. The first case because patient family rejected any other treatment, and the other in combination with chemo and radiotherapy. The authors regard corticoids only to these special cases and do not use it in the patients submited to the combined treatment proposed (surgery plus radiotherapy).

\section{Prognosis}

Complete response is observed in about $63 \%$ of the patients submitted to chemotherapy, but $64 \%$ of the complete responders developed recurrence ${ }^{16}$. Among patient -or tumor- related factors, higher age, worse performance status, presence of B symptom, multiple lesions, presence of meningeal dissemination, and elevated lactate dehydrogenase (LDH) level are associated with poorer survival, whereas no significant difference was observed in prognosis with respect to sex, T/B phenotype, or histological subclassification.

It seems that the influence of various prognostic factors is greater than the effect caused by different types of chemotherapy ${ }^{16}$. Other clinical, biological and radiological prognostic factors found to have a favorable impact on survival are: a) age $<60$ years; b) radiation therapy 
but without evidence of a dose-response relationship; c) radiation therapy in addition to chemotherapy; d) the use of systemic chemotherapy consisting of anthracyclines ${ }^{3}$.

Taxes of recurrence with surgery are directilly proportional to the delay in diagnostic and treatment. Partial surgical resection is also an unfavorable prognostic factor ${ }^{4}$. The prognosis of patients submitted to steretactic biopsy followed by radiotherapy are poorer than those submitted to complete resection plus radiotherapy.

Local recurrence is the most common cause of failure ${ }^{24}$ An also common pattern of PCNSL recurrence is that of cerebrospinal fluid (CSF) dissemination manifested as lymphomatous meningitis $(\mathrm{LM})^{6}$. Literature reports that mean survival time, even with the best treatments is no greater than 18 months $^{5}$. and the 5- and 10-year survival rates are about $15 \%$ and $8 \%$, respectively ${ }^{16}$.

\section{References}

1 Altundag, M.K., Ozisik, Y., Yalcin, S., Akyol, F., Uner, A.: Primary low grade B-cell lymphoma of the dura in an immunocompetent patient. J Exp Clin Cancer Res. 2000; 19: 249-251.

2. Bataille, B.: Treatment of primary cerebral lymphoma. General principles and results Neurochirurgie. 1997; 43: 372375.

3. Bataille, B., Delwail, V., Menet, E., Vandermarcq, P., Ingrand, P., Wager, M., et al.: Primary intracerebral malignant lymphoma: report of 248 cases. J Neurosurg. 2000; 92: 261266.

4. Bataille, B., Page, P.: Prognostic factors and primary cerebral lymphoma Neurochirurgie. 1997; 43: 385-387.

5. Bojanowski, K., Kroh, H., Marchel, A., Sulejman, W.: Primary brain lymphomas. Neurol Neurochir Pol. 2001; 35 : 91-100.

6. Chamberlain, M.C., Kormanik, P., Glantz, M.: Recurrent primary central nervous system lymphoma complicated by lymphomatous meningitis. Oncol Rep. 1998; 5: 521-525.

7. Chamberlain, M.C., Levin, V.A.: Primary central nervous system lymphoma: a role for adjuvant chemotherapy. J Neurooncol. 1992; 14: 271-275.

8. Cheuk, W., Walford, N., Lou, J., Lee, A.K., Fung, C.F., Au, K.H., et al.: Primary histiocytic lymphoma of the central nervous system: a neoplasm frequently overshadowed by a prominent inflammatory component. Am J Surg Pathol. 2001; 25: $1372-1379$.

9. Corn, B.W., Dolinskas, C., Scott, C., Donahue, B., Schultz, C., Nelson, D.F., et al.: Strong correlation between imaging response and survival among patients with primary central nervous system lymphoma: a secondary analysis of RTOG studies 83-15 and 88-06. Int J Radiat Oncol Biol Phys. 2000; 47: 299-303.

10. Cuny, E., Loiseau, H.: Nodular intracerebral lesions can reveal an asymptomatic systemic lymphoma. Acta Neurochir (Wien). 2002; 144: 357- 63.

11. Cuny, E., Loiseau, H., Cohadon, F.: Primary central nervous system lymphomas. Diagnostic and prognostic effect of steroid-induced remission Neurochirurgie. 1998; 44: 19-24

12. Delwail, V., Bataille, B.: Chemotherapy of primary cerebral lymphoma. Neurochirurgie 1997; 43: 380-384.

13. Fewings, P.E., Bhattacharyya, D., Crooks, D., Morris, K.: B cell non-Hodgkin cerebral lymphoma associated with an anaplastic oligodendroglioma. Clin Neuropathol. 2002; 21 : 243-247.

14. Gildenberg, P.L., Gathe, J.C. Jr., Kim, J.H.: Stereotactic biopsy of cerebral lesions in AIDS. Clin Infect Dis. 2000; 30: 491-499.

15. Gliemroth, J., Kehler, U., Gaebel, C., Arnold, H., Missler, U.: Neuroradiological findings in primary cerebral lymphomas of non-AIDS patients. Clin Neurol Neurosurg. 2003; 105: 78-86.

16. Hayabuchi, N., Shibamoto, Y., Onizuka, Y.: Primary central nervous system lymphoma in Japan: a nationwide survey. Int J Radiat Oncol Biol Phys. 1999; 44: 265-272.

17. Kolasa, P., Kordek, R.: Coexistence of diffuse large B-cell lymphoma within pontocerebellar angle schwannoma. Folia Neuropathol. 2002; 40: 107-110.

18. Mead, G.M., Bleehen, N.M., Gregor, A., Bullimore, J., Shirley, D., Rampling, R.P., et al.: A medical research council randomized trial in patients with primary cerebral non-Hodgkin lymphoma: cerebral radiotherapy with and without cyclophosphamide, doxorubicin, vincristine, and prednisone chemotherapy. Cancer. 2000; 89:,1359-1370.

19. Monobati, A., Rakei, S.M., Kumar, P., Taghipoor, M., Rahimi, A.: Primary burkitt lymphoma of the brain in na immunocompetent patient. Case report. J Neurosurg. 2002; 96: 1127-1129.

20. Park, D.M., Abrey, L.E.: Pharmacotherapy of primary CNS lymphoma. Expert Opin Pharmacother. 2002; 3: 39-49.

21. Paueksakon, P., Shaya, M., Harper, R., Hicks, J., Truong, L., Goodman, J.C., et al.: Local cryoglobulin deposition in primary central nervous system lymphoma. Hum Pathol. 2003; 34: 720-724.

22. Sawin, P.D., Hitchon, P.W., Follett, K.A., Torner, J.C.: Computed imaging-assisted stereotactic brain biopsy: a risk analysis of 225 consecutive cases. Surg Neurol. 1998; 49: 640649.

23. Shibamoto, Y., Sasai, K., Oya, N., Hiraoka, M.: Systemic chemotherapy with vincristine, cyclophosphamide, doxorubicin and prednisolone following radiotherapy for primary central nervous system lymphoma: a phase II study. J Neurooncol. 1999; 42: 161-167

24. Shibamoto, Y., Tsutsui, K., Dodo, Y., Yamabe, H., Shima, N., Abe, M.: Improved survival rate in primary intracranial lymphoma treated by high-dose radiation and systemic vincristine-doxorubicin-cyclophosphamide-prednisolone che- 
motherapy. Cancer. 1990; 65: 1907-1912.

25. Singhal, D., Witham, T.F., Germanwala, A., Flickinger, J.C., Schiff, D., Kondziolka, D.: Multi-modality therapy leads to longer survival in primary central nervous system lymphoma patients. Can J Neurol Sci. 2002; 29: 147-153.

26. Sonstein, W., Tabaddor, K., Llena, J.F.: Solitary primary CNS lymphoma: long term survival following total resection. Med Oncol. 1998; 15: 61-65.

27. Spinelli, F., Sara, R., Milella, M., Ruffini, L., Sterzi, R., Causarano, I.R., et al.: Technetium-99m hexamethylpropylene amine oxime leucocyte. Eur J Nucl Med. 2000; 27: 46-49.

28. Takeshita, M., Kubo, O., Tajika, Y., Kawamoto, T., Hori, T., Takakura, K.: Primary central nervous system T-cell lymphoma. Case report. Neurol Med Chir 1999; 39: 452-458.

29. Tseng, S.H., Liao, C.C., Lin, S.M., Chen, Y., Shun, C.T.: Dural metastasis in patients with malignant neoplasm and chronic subdural hematoma. Acta Neurol Scand. 2003; 108: 43-46.

30. Uchino, M., Kitajima, S., Yokota, K., Nagao, T., Seiki,
2006; 17: 46-53

Y., Shibata, I., et al.: A rare massive parenchymal metastasis in central nervous system from abdominal non-Hodgkin lymphoma: effectiveness of stereotactic radiosurgey: case report. No To Shinkei. 2003 55: 273-276.

31. Yang J, Yuan G. Primary intracranial malignant lymphoma: report of 40 cases

Zhonghua Wai Ke Za Zhi. 1996: 34:102-3.

32. Yu, H., Xie, Y., Wang, G.: The clinical features and prognostic factors of 22 patients with primary central nervous system lymphoma. Zhonghua Nei Ke Za Zhi. 2001; 40: 325328.

Alécio-Mattei, T.; Alécio-Mattei, J.; Aguiar, P.H.; Ramina, R.: Primary central nervous system lymphomas in immunocompetent patients. Neurocirugía 2006; 17: 46-53.

Correspondence to: Dr. Tobias Alécio Mattei. Rua Capote Valente 725 ap. 302. CEP (postal-code) 05409-002 São Paulo - SP - Brazil. 